\title{
FEROMONI MEDONOSNE PČELE (Apis mellifera L.)
}

\author{
Marin Kovačić, Zlatko Puškadija
}

\begin{abstract}
Sažetak
Podjelu uloga između članova pčelinje zajednice, kao i funkcioniranje pčelinje zajednice omogućuje savršena komunikacija, a ona se kod pčela odvija pomoću pčelinjeg plesa i najvećim dijelom putem feromona. Feromoni u pčelinjoj zajednici imaju ulogu spajanja pčela kao jedinki u jednu kohezivnu zajednicu, tzv. superorganizam. Također, feromoni imaju ključnu ulogu u svim aspektima života pčelinje zajednice, od razmnožavanja, do sakupljanja hrane i obrane zajednice. U ovom su radu obrađene žlijezde koje izlučuju feromone, kao i uloga pojedinih feromona na ponašanje pčelinje zajednice.
\end{abstract}

Ključne riječi: medonosna pčela, feromoni, žlijezde, komunikacija

\section{Uvod}

Medonosna pčela (Apis mellifera L.) pripada redu opnokrilaca (Hymenoptera) i živi u socijalnoj zajednici s nekoliko desetaka tisuća radilica, nekoliko stotina trutova i maticom. Svaka jedinka ima točno određenu ulogu i funkciju u zajednici. Podjelu uloga i funkcioniranje zajednice omogućuje savršena komunikacija, a ona se kod pčela odvija pomoću dodira, pčelinjeg plesa i feromona. Feromoni su kemijske tvari koje izlučuju egzokrine žlijezde životinja i izazivaju promjenu u ponašanju ili fiziologiji druge jedinke iste vrste te tako djeluju kao kemijska poruka (Karlson i Luscher, 1959.).

Socijalni kukci komuniciraju kemijskim jezikom koji ima jednak učinak kao vizaulna i zvučna komunikacija između viših kralježnjaka (Bell i Carde, 1984.). Feromonski signali kod pčela često su uvjetovani složenošću, sinergijom i kontekstom u kojem su raspoređeni, kao i načinom posredovanja, bilo vremenskom ili prostornom distribucijom (Slessor i sur., 2005.). Organizacija pčelinje zajednice je uglavnom određena putem kemijske signalizacije, čije signale aktivno proizvode i emitiraju radilice različite dobi, matica, leglo i trutovi. Feromoni su uključeni u gotovo sve aspekte života pčelinje zajednice: razvoj i razmnožavanje, skupljanje hrane, obrana, orijentacija i općenito u sve aktivnosti zajednice.

Pčele feromone mogu prepoznati u obliku mirisa ili okusa, a percipiraju ih pomoću specijaliziranih osjetilnih stanica - kemoreceptora. Primarni mirisni organi pčele su ticala koja ispod tvrdog sloja hitina prožetog rupicama sadrže kemoreceptorne stanice za miris. Neki feromoni su slabo isparljivi i prije svega se prenose oralnim kontaktom a percipiraju ih kemoreceptorne stanice smještene u usnoj šupljini. Takvi feromoni se nazivaju kontaktni feromoni (Blum, 2000.).

Feromoni se izlučuju u tekućem obliku, šire se kao tekućina ili plin (Free, 1987.) i imaju vrlo usko specifično djelovanje. Kod pčela djeluju na dva načina: mogu imati trenutni učinak (releaser effect) ili dugotrajni učinak (primer effect) (Wilson i Bossert, 1963). Feromoni koji imaju trenutni učinak izazivaju gotovo trenutnu promjenu u ponašanju primatelja signala

Marin Kovačić dipl.ing.agr., prof.dr.sc. Zlatko Puškadija, Poljoprivredni fakultet u Osijeku, Sveučilište J.J. Strossmayera u Osijeku, Vladimira Preloga 1, 31000 Osijek, Hrvatska

Dopisni autor/Corresponding author: prof.dr.sc. Zlatko Puškadija; e-mail: zlatko.puskadija@pfos.hr 
posredovanjem živčanog sustava. Većina poznatih feromona spada u ovu skupinu (npr. alarmni feromoni, seksualni atraktanti, skupljanje u roj, orijentacija). Feromoni s dugotrajnim učinkom imaju dugoročni utjecaj na endokrini i reproduktivni sustav primatelja signala (npr. matični feromon inhibira razvoj jajnika kod radilica). Pojedini multifunkcionalni feromoni mogu imati i trenutni i dugotrajni učinak, kao što su primjerice mandibularni feromon matice $\mathrm{i}$ feromoni legla (Traynor i sur., 2014.).

Feromonska komunikacija najviše je istraživana kod medonosnih pčela (A. mellifera L.) zbog njihove velike rasprostranjenosti i dostupnosti, ekonomske važnosti kao i velikog zanimanja čovjeka za organizaciju i ustrojstvo pčelinje zajednice (Dražić i Kezić, 2000.).

\section{Žlijezde koje izlučuju feromone}

Proizvodnja i izlučivanje feromona u pčelinjoj zajednici ovisi o spolu (žlijezde koje posjeduje jedinka), starosti i ulozi jedinke u zajednici. Na slici 1. prikazane su poznate žlijezde kod radilice i matice. Najveći dio feromona kod pčela izlučuje se iz: madnibularne (prednjočeljusne) žlijezde, Nasanovljeve žlijezde, Koschewnikove žlijezde, tergitne žlijezde (žlijezde trbušnih ljuščica egzoskeleta matice), Dufourove žlijezde, stopalne (tarzalne) žlijezde, voštane žlijezde, rektuma matice, ovojnice na bazi žalca i pčelinjeg legla.

\section{Prednjočeljusna (mandibularna) žlijezda}

Prednjočeljusna žlijezda je parna žlijezda razvijena kod radilica i trutova, a posebno dobro razvijena kod matice. Žlijezda se nalazi u glavi iznad baze prednjih čeljusti i kratkim cjevčicama je spojena s dnom čeljusti kroz koju se izlučuju sekreti. U sekretu prednjočeljusne žlijezde matice pronađeno je 24 sastojka (Winston, 1987.), od kojih su mnogi još neidentificirani. Dokazan je feromonski učinak 5 spojeva prednjočeljusne žlijezde: 9-keto-2dekanske kiseline (9-ODA), oba optička izomera 9-hidroksi-2-dekanske kiseline (9-HDA), metil p-hidroksibenzoata (HOB) i 4-hidroksi-3-metaksifenil etanola (HVA) (Free, 1987., Slessor i sur., 1988.). Feromoni prednjočeljusne žlijezde matice imaju ulogu u privlačenju trutova prilikom sparivanja, sprječavanju razvoja matičnjaka, inhibiranju razvoja jajnika kod radilica, zadržavanju radilica u blizini legla i u okupljanju pčela za vrijeme rojenja. Radilice $u$ mandibularnim žlijezdama proizvode sekrete koje sadrže kiseline od 10 i 8 ugljikovih atoma. Kod mladih pčela hraniteljica, žlijezda izlučuje bijelu tvar bogatu lipidima koja pomiješana sa sekretima podždrijelne žlijezde čini radiličku i matičnu mliječ kojom se ishranjuju radilice $\mathrm{i}$ matica. Kada hraniteljice postanu čuvarice i sakupljačice, u njihovim prednjočeljusnim žlijezdama stvara se vrlo mirisni spoj, 2-heptanon (2-HP), koji ima važnu ulogu u obrani pčelinje zajednice (Shearer i Boch, 1965.). U prednjočeljusnim žlijezdama trutova proizvode se feromoni zaslužni za okupljanje trutova na mjestima pogodnim za parenje s maticom (okupljališta trutova).

\section{Tergitne žlijezde}

Tergitne žlijezde nalaze se na leđnoj strani zatka matice između četvrtog i šestog kolutića. Radilice i trutovi ih nemaju. Ove žlijezde izlučuju feromone koji imaju ulogu u privlačenju pčela, sprječavanju razvoja matičnjaka i inhibiranju razvoja jajnika kod radilica (Velthuis, 1970.). Izlučevine tergitne žlijezde sastoje se od dugolančanih masnih kiselina (glavna komponenta je 9-oktadekanska kiselina), dugolančanih estera i nezasićenih ugljikovodika (Wossler i Crewe, 1999.). Proizvodnja sekreta tergitne žlijezde počinje nakon sparivanja. 
Smith i sur. (1993.) su dokazali kako su matice nakon prirodnog sparivanja počele lučiti feromone iz tergitnih žlijezda, dok umjetno sparene matice nisu. Tako je napokon bio objašnjen tehnološki problem težeg prihvata umjetno oplođenih matica u pčelinjoj zajednici.

\section{Tarzalne žlijezde}

Radilice hodanjem ponekad iza sebe ostavljaju uljast, bezbojan sekret slabe isparljivosti koji ima utjecaj na ponašanje drugih radilica na ulazu u košnicu ili na cvijeću (Free, 1987.). Sekret je nazvan feromon traga. Izlučuju ga radilice i matice, međutim imaju različitu funkciju. Feromon traga matice skupa sa sekretom prednjočeljusne žlijezde sprječava izvlačenje matičnjaka u prenapučenim pčelinjim zajednicama. Matica stara šest mjeseci izlučuje više feromona od dvogodišnje matice, a radilice izlučuju 10-15 puta manje sekreta od matice (Lensky i sur., 1984.). Radilice na ulazu u košnicu putem tarzalnih žlijezda ostavljaju stalan feromonski trag koji uz pomoć mirisa Nasanovljeve žlijezde pomaže dezorijentiranim pčelama pronalazak ulaza u košnicu (Ferguson i Free, 1981.).

\section{Nasanovljeva (mirisna) žlijezda}

Mirisna Nasanovljeva žlijezda nalazi se na dorzalnoj strani zatka radilica ispod površine sedmog kolutića. Matice i trutovi ju nemaju. Žlijezda se sastoji od 500-600 žljezdanih stanica od kojih svaka stanica ima svoj kanal za izlučivanje (Cassier i Lensky, 1994.). Sekret mirisne žlijezde nakuplja se u mirisnom kanalu koji je normalno pokriven. Kada pčela razmakne 6. i 7. kolutić i izboči mirisnu žlijezdu, oslobađa se miris iz kanala, a žlijezda je vidljiva golim okom. Pri tome podigne zadak i ventilira krilima kako bi što više raširila miris žlijezde u određenom smjeru (Snodgras, 1956.). Feromoni mirisne žlijezde djeluju kao atrakanti i imaju važnu ulogu u privlačenju radilica prilikom skupljanja u roj $\mathrm{i}$ u pomaganju pronalaska košnice dezorijentiranim radilicama nakon uznemiravanja. Nasanovljev feromon danas se jednostavno i jeftino sintetizira i u praksi se koristi u privlačenju rojeva na željeno mjesto (klopka za roj).

\section{Koschewnikova žlijezda}

Koschewnikova žlijezda se nalazi u blizini žalčanog aparata i sastoji se od nakupina stanica u komori žalca. Puno je bolje razvijena kod matica nego kod radilica i imaju različitu funkciju. Sekreti Koschewnikove žlijezde matice su privlačni za radilice (Butler i Simpson, 1965.), no nakon godine dana starosti, žlijezda degenerira (Grandperrin i Cassier, 1983.). Sekreti Koschewnikove žlijezde radilica imaju važnu ulogu kao alarmni feromon i u njima je pronađeno više od 40 kemijskih spojeva, od kojih je najznačajniji izopentil-acetat (IPA)(Boch i sur., 1962.).

\section{Dufourova žlijezda}

Dufourova žlijezda je neparna i nerazgranata i oblika je vrećice, a posjeduju je matice i radilice. Obložena je jednostrukim slojem epitelnih stanica čija je luminalna strana prekrivena kutikulom. Na površini žlijezde nalaze se mišići koji služe za pražnjenje izlučevina žlijezde. Žlijezda je spojena s vaginalnim kanalom na području dorzalne vaginalne stjenke (Martin i sur., 2005.). Izlučevine žlijezde prisutne su na izleženim oplođenim jajima, stijenci vagine i na vrhu zatka matice (Katzav-Gozansky i sur., 2001.). Sekreti žlijezde matice i liježućih radilica (tzv. lažnih matica) sadrže ugljikohidrate i estere, dok izlučevine žlijezda običnih radilica sadrže samo ugljikohidrate (Katzav-Gozansky i sur., 1997.). Ta razlika u sastavu je vrlo bitna 
jer je dokazano da esteri iz izlučevina matica uzrokuju privlačenje pčela pratilja (KatzavGozansky i sur., 2003.), tako da samo izlučevine Dufourove žlijezde matice privlače radilice.

\section{Voštane žlijezde}

Voštane žlijezde smještene su na trbušnoj strani zatka od 4. do 7. kolutića. Na svakom kolutiću nalazi se 2 otvora za izlučivanje voska (Snodgrass, 1956.). Voštane žlijezde pčela sastoje se od tri tipa stanica: epitelnih stanica, oenocita i adipocita. Stanice sinergijski luče vosak koji je kompleksna smjesa ugljikovodika, masnih kiselina i bjelančevina. Voštane žlijezde najaktivnije su kod mladih radilica starosti 12-18 dana. Vosak se luči u tekućem obliku i stvrdne se u obliku tankih listića. Pomoću prednjih nogu i čeljusti, radilice od voštanih listića izgrađuju saće. Za izgradnju $1 \mathrm{~kg}$ voska pčele potroše $8,4 \mathrm{~kg}$ meda (Whitcomb, 1946.).

\section{Feromoni - protok informacija i kolektivno odlučivanje}

Feromoni obično djeluju zajedno, u sinergiji. Primjerice, u alarmiranju zajednice na opasnost djeluju feromoni žalčanog aparata i prednjočeljusne žlijezde radilica, a u inhibiciji razvoja jajnika kod radilica djeluju feromoni legla i matični feromon. Stoga je najbolje djelovanje feromona opisati putem ponašanja i reakcija pčela u zajednici.

\section{Matični feromon - središnji feromon pčelinje zajednice}

Matica svoju prisutnost u zajednici pokazuje pomoću matičnog feromona koji se sastoji od 9 komponenti: 5 komponenti iz prednjočeljusne žlijezde (9-ODA, 2 izomera 9-HDA, HOB i HVA)(Slessor i sur., 1988.) i 4 dodatna feromona drugih žlijezdi (metil oleata, koniferil alkohola, palmitilnog alkohola i linolenske kiseline)(Keeling i sur., 2003.). Matični feromon ima središnju ulogu u pčelinjoj zajednici. Točnije, matični feromon ima utjecaj na koheziju radilica, inhibira razvoj jajnika kod radilica i stimulira aktivnost radilica: čišćenje, građenje, unos hrane i ishrana legla. Nekoliko sati (12-24) nakon gubitka jasnog znaka o prisutnosti matičnog feromona, pčele počinju izvlačiti matičnjake. Dugoročnim izostankom matičnog feromona, skupa s izostankom legla, kod radilica se počinju razvijati jajnici i one počinju lijegati neoplođena jaja iz kojih se izliježu trutovi. Zajednica postaje neorganizirana, prljava, podložna bolestima i predatorima te ubrzo propada.

Prvo uočeno svojstvo matičnog feromona je privlačenje radilica prema matici. Matica je na okviru obično okružena s 8-10 pčela pratilja koje ju hrane. Za uzvrat dobiju malo dragocjenog feromona kojeg uzimaju s tijela matica lizanjem, ticalima i prednjim nogama te ga dalje šire po zajednici. Matični feromon ima značajnu ulogu u razmnožavanju pčela jer inhibira razvoj jajnika kod radilica (Hoover i sur., 2003.) i sprječava izgradnju matičnjaka tj. novih matica (Winston i sur., 1990.). Feromon se brzo širi u pčelinjoj zajednici putem socijalne izmjene hrane između radilica. Problem se javlja kada se zajednica razvije i ima puno jedinki. Tada se matični feromon teže širi, ne dospijeva do svih dijelova košnice i manje je učinkovit (Nauman i sur., 1993.). Zbog prenapučenosti, feromon se razrijedi i ne prenosi, a radilice se počinju ponašati kao da nemaju maticu i počinju izvlačiti matičnjake. Obilježje socijalnih kukaca je reproduktivna specijalizacija. Matica jedina leže oplođena jaja dok fakultativno sterilne radilice predstavljaju radnu snagu. Iako se radilice ne mogu spariti, zadržale su svojstvo razvoja jajnika i mogu izleći neoplođena jaja iz kojih će se razviti muške jedinke - trutovi. U normalnoj pčelinjoj zajednici samo $0,01 \%$ radilica ima potpuno razvijene jajnike (Ratnieks, 1993.). 


\section{Obrana pčelinje zajednice - alarmni feromoni}

Jedna od najvažnijih prednosti socijalnih kukaca je organizirana obrana zajednice, legla i zaliha hrane (Breed i sur., 2004.). Alarmne feromone izlučuju prednjočeljusna i Koschewnikova žlijezda. Obrana pčelinje zajednice je kompleksna kombinacija promjena u ponašanju radilica djelomično uzrokovana feromonima (Pankiw, 2004.). Organizaciju obrane pčelinje zajednice čine pčele stražarice, koje čuvaju ulaz u košnicu, i pčele vojnici, koje sudjeluju u napadu na prijetnju (Breed i sur., 1992.). Obrana zajednice počinje ispuštanjem alarmnog feromona od strane čuvarica koje na taj način pozivaju ostale radilice na ulaz u košnicu (Alaux i Robinson, 2007.). Reakcija radilica na prijetnju sastoji se od slijeda događaja od kojih svaki idući predstavlja pojačanu obrambenu reakciju. Prvo čuvarica opaža potencijalnu prijetnju, orijentira se i identificira ju. Ako prijetnja nije ustanovljena sa sigurnošću, dolazi do kontakta s ticalima i sekundarne identifikacije. Ova identifikacija ticalima ima vrlo važnu ulogu u razlikovanju radilica iz košnice i radilica-uljeza. Ako je prijetnja ustanovljena dolazi do alarmiranja ostalih radilica i napada ubadanjem (Breed i sur., 1992.). Prilikom uboda, radilica iz žalca ispušta mješavinu tvari koja upozorava i angažira ostale radilice na obranu zajednice (Breed i sur., 2004.). Do sada je izdvojeno više od 40 komponenti iz ekstrakta žalčanog aparata (Blum i Fales, 1988), a oko 15 spojeva utječe na alarmiranje pčela (Pankiw, 2004.). Najznačajnije tvari alarmnog feromona su izopentil acetat (IPA) iz žalčanog aparata (Boch i sur., 1962.) i 2-heptanon (2-HP) iz prednjočeljusne žlijezde (Shearer i Boch, 1965.). Upravo IPA i 2-HP najviše izazivaju ubadanje radilica i odbijaju druge radilice od ulaza u košnicu (Boch i sur., 1970., Free i sur., 1983., Morse, 1972.).

Osnovna uloga IPA je alarmiranje i angažiranje radilica. Nakon uboda, žalac ostaje u tijelu žrtve i izlučuje vrlo hlapljiv IPA te na taj način drugim pčelama predstavlja oznaku gdje trebaju napadati (Pankiw, 2004.). Pickett i sur. (1982.) identificirali su slabije isparljiv spoj, oktadekanol, koji produljuje aktivnost IPA smanjujući njeno hlapljenje. Mješavina IPA i oktadekanola je duže aktivna od samog IPA. Osim „označavanja mete“, IPA ima ulogu i u poticanju radilica za traženjem opasnosti i povećanju brzine obrambene reakcije (Wager i Breed, 2000.). Nakon duže izloženosti IPA, reakcija zajednice se povećava, tj. zajednica je agresivnija (Alaux i Robinson, 2007.). Moguće je da IPA omogućuje zajednici bržu i jaču reakciju na prijetnju koja je već prije identificirana. Ovaj fenomen je analogan imunološkoj memoriji sisavaca, čije je temeljno obilježje adaptivni imunosni sustav. U tom kontekstu, čuvarice predstavljaju memorijske T-stanice jer brže i snažnije reagiraju na prijetnju koja je prije identificirana (Alaux i sur., 2010.).

Uloga 2-HP je vjerojatno u obilježavanju uljeza prilikom ugriza radilice, koji na taj način postaje prepoznatljiv za ostale radilice (Free, 1987.). Osim toga, radilice pomoću 2-HP obilježavaju cvjetove dok ne luče nektar te svojim repelentnim učinkom odbija pčele od cvijeta.

\section{Podjela poslova u pčelinjoj zajednici}

Pčelinju zajednicu karakterizira raspodjela poslova između jedinki. Raspodjela poslova uglavnom je uvjetovana starošću radilica. Prva 2 do 3 tjedna života radilice provode u košnici (hrane i brinu se o leglu, izgrađuju saće, čiste stanice saća), a ostatak života provode čuvajući ulaz u košnicu i skupljajući hranu i vodu (Robinson, 1992). Promjena u obavljanju poslova uvjetovana je količinom juvenilnog hormona $\mathrm{u}$ hemolimfi radilica, koja se povećava $\mathrm{s}$ 
povećanjem dobi (Huang i sur., 1991.). Osim juvenilnog hormona, ulogu u raspodjeli poslova u zajednici imaju i feromoni. Omjer hraniteljica i skupljačica je vrlo bitan čimbenik u funkcioniranju zajednice te je s toga vrlo fleksibilan i ovisno o potrebama zajednice radilice će duže biti hraniteljice ili će ranije postati skupljačice. Matični feromon (MF) usporava prelazak hraniteljica u skupljačice (Pankiw i sur., 1998.). Visoke količine feromona legla produljuju dio života radilice kao hraniteljice (Le Conte i sur., 2001.) zbog potrebe ishrane legla i na taj način ima dugoročni učinak. No feromoni legla također imaju i trenutni učinak. Nekoliko sati nakon izlaganja feromonima legla, skupljačice počinju s pojačanim unosom peludi neophodnog za razvoj legla (Pankiw i Page, 2001.). Skupljačice također usporavaju prelazak hraniteljica u skupljačice proizvodnjom etil oleata (EO). EO, kojeg osim skupljačica izlučuju matica i leglo, pospješuje razvoj podždrijelne žlijezde kod hraniteljica. S druge strane, izlučevine hraniteljica potiču raniji prelazak mladih radilica u skupljačice.

Feromoni koji prevladavaju u košnici utjecat će na raspodjelu poslova. Primjerice, ako iz nekog razloga u kratkom vremenu nestane puno skupljačica, u zajednici će biti manjak etil oleata i doći će do bržeg prelaska hraniteljica u skupljačice. Kada roj dođe na novo mjesto, najveći posao je izgradnja novog saća za razvoj legla i skladištenje hrane. Tada matični feromon stimulira izlučivanje voska kod radilica i izgrađivanje samo radiličkog saća.

\section{Privlačnost - Nasanovljev feromon}

Pomoću Nasanovljevog feromona pčele obilježavaju ulaz u košnicu, označavaju izvor hrane, a veliku ulogu ima prilikom okupljanja radilica u roj. Mlade radilice prilikom prvog orijentacijskog leta također izlučuju feromon. Radilice na letu košnice izlažu Nasanovljevu žlijezdu i ventilirajući krilima šire feromon koji pomaže drugim pčelama u orijentaciji i lakšem pronalasku košnice. Izlučivanje feromona je posebno vidljivo prilikom uznemiravanja pčelinje zajednice, a može biti izazvano mirisima zajednice, kao što su okviri, med, pelud, propolis i matični feromon (Ferguson i Free, 1981.). Radilice na izvoru hrane ili vode izlažu Nasanovljevu žlijezdu pomažući tako drugim skupljačicama lakši pronalazak izvora hrane. Prilikom izlaganja žlijezde na cvijetu, pčele ne lepezaju krilima pa širenje feromona nije usmjereno. Stout i Goulson (2001.) su ustanovili kako radilice više obilaze cvjetove koji su bili posjećeni u protekla 24 sata nego one koji nikad nisu bili posjećeni.

Prilikom rojenja, radilice koje prve pronađu maticu koja izlučuje matični feromon, počinju izlučivati Nasanovljev feromon kako bi pomogle ostalim radilicama i roj se vrlo brzo okupi oko matice. Nasanovljev feromon ima čak i važniju funkciju u okupljanju radilica oko matice prilikom rojenja od matičnog feromona.

Nedavna istraživanja su otkrila novu ulogu Nasanovljevog feromona u košnici. Radilice koje odabiru tek izlegnute ličinke za uzgoj buduće matice izlažu žlijezdu i privlače druge radilice prema odabranoj ličinki. Al-Kahtani i Bienefeld (2012.) su u svom istraživanju u obezmatičenoj zajednici pokazali kako su matičnjaci oko kojih je bilo više Nasanovljenvog feromona bili okruženi s više radilica te su tako imali bolje uvjete za razvoj.

\section{Feromoni trutova}

Sparivanje se matica odvija u zraku, na visini od 10 do 40 m (Ruttner, 1966.). Trutovi se okupljaju na određenim prostorima koja se nazivaju okupljališta ili sparivališta trutova (Zmarlicki i Morse, 1963.). To je zračni prostor veličine 30 do $300 \mathrm{~m} \mathrm{u}$ koji dolaze trutovi 
nekoliko godina zaredom. Pretpostavlja se da su to mjesta najpristupačnija trutovima i najprikladnija za sparivanje na tom području. Na okupljalištu trutova može biti i 10000 trutova iz okolice 5-6 km (Free, 1987.). Trutovi u prednjočeljusnim žlijezdama izlučuju feromone koji privlače nesparene matice i druge trutove na sparivalište. Kada matica dođe na područje sparivališta, prisutnost velikog broja trutova i matičnog feromona koji privlači trutove omogućuje brzo sparivanje matice s trutovima (10-20). Na taj se način smanjuje rizik stradanja matica od predatora, a kako se na tom malom području nalazi veliki broj trutova iz šire okoline, mogućnosti za križanje u srodstvu su minimalne.

\section{Feromoni legla}

$\mathrm{Na}$ površini ličinki otklopljenog legla nalaze se feromoni koji imaju važnu ulogu u komunikaciji između ličinki i radilica. Feromoni legla se sastoje od etilnih i metilnih estera (palmitinske, linolenske, linoleinske, stearinske i oleinske kiseline) i 3,7-dimeti-1,3,6-triene (E- $\beta$-ocimene) (Arnold i sur., 1994., Maisonnasse i sur., 2009.). Oni utječu na hranidbenu aktivnost radilica, inhibiraju razvoj jajnika kod radilica, potiču radilice u određenom trenutku na poklapanje legla, povećavaju aktivnost podždrijelne žlijezde hraniteljica i utječu na duljinu faze života radilice kao hraniteljice. Pojedinačno, feromoni imaju djelomičan utjecaj, tek zajedničkim djelovanjem matičnog feromona i feromona legla dolazi do inhibicije razvoja jajnika kod radilica (Alaux i sur., 2010.). Feromoni legla šire se kontaktom i imaju dugotrajni i trenutni učinak.

\section{Feromoni voska}

Mlade radilice s razvijenim voštanim žlijezdama izlučuju voštane listiće koje pomoću sekreta žlijezda slinovnica i prednjočeljusnih žlijezda lijepe u šestorokutne stanice saća. Saće radilice koriste za uzgoj legla te skladištenje peludi i meda. Za uzgoj trutova radilice prave veće stanice (promjera 6,2-7,0 mm), dok za radiličko leglo prave manje stanice (promjera 5,36,3 mm; Jay, 1963.). Matičnjak je stanica na saću u kojem se razvija matica i on je većih dimenzija. Nakon izlijeganja radilice ili truta, mlade radilice čiste (poliraju) stanice saća dok ne dobiju lakirani izgled. Poslije svake generacije izlegnutih pčela u stanici saća ostaje košuljica presvučene pčele i saće dobiva sve tamniju boju.

Feromoni u vosku najveći utjecaj imaju na unos nektara u košnicu. Istraživanja su pokazala kako zajednice s više praznog saća unose i do 30\% više nektara (Rinderer i Baxter, 1979.; Rinderer i Hagstad, 1984.). Osim na unos nektara, prazne stanice saća potiču pojačanu obranu košnice. Radilice za uzgoj legla i skladištenje hrane radije biraju starije od novo izgrađenog saća. Nove stanice saća sadrže samo sekrete pčelinjih žlijezda, a starije saće sadrži košuljice $\mathrm{i}$ feces ličinki. U starijem saću se nalazi i određena količina feromonskog traga matice i radilica (Free, 1987.) te je zato i privlačnije pčelama.

\section{Zaključak}

Feromoni imaju vrlo važnu ulogu u regulaciji funkcionalnosti pčelinje zajednice. Pojedini feromoni su monofunkcionalni (Nasanovljev feromon koji djeluje sam), a pojedini su multifunkcionalni (matični feromoni i feromoni legla skupa inhibiraju razvoj jajnika kod radilica). Feromoni se izlučuju prema potrebama zajednice. Ukoliko je u košnici prisutno puno otklopljenog legla, prevladavat će esteri legla koji produljuju životnu fazu kućne pčele kao 
hraniteljice. Ukoliko je prisutno malo legla i puno praznog saća, kućne pčele će prije postati skupljačice i priključiti se unosu hrane. Dezorijentirane i izgubljene radilice ispred košnice pomoću Nasanovljevog feromona koji ispuštaju druge radilice bez problema nalaze svoju košnicu. Na vrhuncu svoga razvoja, kada je u košnici veliki broj radilica, feromoni su jedan od razloga zašto dolazi do rojenja. Tada matični feromon i feromon traga matice ne dospijeva do svih radilica i one počinju izvlačiti matičnjake i uzgajati novu maticu. Veliki broj skupljačica utječe na fiziologiju kućnih pčela inhibirajući njihov razvoj tijekom unosa nektara i peludi. Budući da je djelovanje feromona složeno potrebno je provesti dodatna istraživanja, kako bi se bolje razjasnila njihova uloga, jer kemijska komunikacija socijalnih kukaca ima jednaku ili čak i veću razinu složenosti od sustava komuniciranja kralješnjaka.

\section{LITERATURA}

1. Alaux, C., Robinson, G.E. (2007): Alarm pheromone induces immediate-early gene expression and alow behavioral response in honey bees. Journal of Chemical Ecology, (33): 1346-1350.

2. Alaux, C., Maisonnasse, A., Le Conte, Y. (2010): Pheromones in a superorganism: from gene to social regulation. Vitamins and Hormons, (83): 401-423.

3. Al-Kahtani, S.N, Bienefeld, K. (2012): The Nasonov gland pheromone is involved in recruiting honey bee workers for individual larvae to be reared as queens. Journal of Insect Behavior, (25): 392-400.

4. Arnold, G., Le Conte, Y., Trouiller, J., Hervet, H., Chappe, B., Masson, C. (1994): Inhibition of worker honeybee ovaries development by a mixture of fatty acid esters from larvae. Comptes Rendus de I Académie des Sciences - Series III, (317): 511-515.

5. Bell, W. J. i Carde, R. T. (1984): Chemical Ecology of Insects. Chapman and Hall, London

6. Blum, M.S., Fales, H.M. (1988): Eclectic chemiosociality of the honeybee: a wealth of behaviors, pheromones, and exocrine glands. Journal of Chemical Ecology, (14): 2099-2107.

7. Blum, M.S. (2000): Honey bee pheromones. The Hive And The Honey Bee, Dadant \& Sons, Hamilton, Illinois

8. Boch, R., Shearer, D. A., Stone, B. C. (1962): Identification of iso-pentyl acetate as an active component in the sting pheromone of the honey bee. Nature, (195): 1018-1020.

9. Boch, R., Shearer, D.A.. Petrasovits, A. (1970): Efficacies of two alarm substances of the honeybee. Journal of Insect Physiology, (16): 17-24.

10. Breed, M.D., Smith, T.A., Torres, A. (1992): Role of guard honey bees (Hymenoptera: Apidae) in nestmate discrimination and replacement of removed guards. Annals of the Entomological Society of America, (85): 633-637.

11. Breed, M.D., Guzman-Novoa, E., Hunt, G.J. (2004): Defensive behavior of honey bees: organization, genetics, and comparisons with other bees. Annual Review of Entomology, (49): 271-298.

12. Butler, C.G., Simpson, J. (1965): Pheromones of the honeybee (Apis mellifera L.) an olfactory pheromone from the Koschewnikow gland of the queen. Vedecke Prace, Sci. Studies, Univ. Libcice, Czech (4): 33-36. 
13. Cassier, P., Lensky, Y. (1994): The Nassanov gland of the workers of the honeybee (Apis mellifera L.): Ultrastructure and behavioural function of the terpenoid and protein components. Journal of Insect Physiology, (40): 577-584.

14. Dražić, M., Kezić, N. (2000): Feromoni pčela. Central European Journal Of Agriculture, Vol 1(1): 18.

15. Ferguson, A.W., Free, J.B. (1981): Factors determining the release of Nasonov pheromone by honeybees at the nest entrance. Physiological Entomology, (6): 15-19.

16. Free, J.B. (1987.): Pheromones of social bees. Chapman and Hall, London

17. Free, J.B., Ferguson, A.W., Jasqueline, R., Simpkins, R., Al-Sa'ad, B.N. (1983): Effect of honeybee Nasonov and alarm pheromone components on behaviour at the nest entrance. Journal of Apicultural Research, 22(4): 214-223.

18. Grandperrin, D, Cassier, P. (1983): Anatomy and ultrastructure of the Koschewnikow's gland of the honey bee, Apis mellifera L. (Hymenoptera: Apidae) International Journal of Insect Morphology and Embryology, 12(1): 25-42.

19. Hoover, S.E.R., Keeling, C.I., Winston, M.L., Slessor, K.N. (2003): The effect of queen pheromones on worker honey bee ovary development. Naturwissenschaften, (90): 477-480.

20. Huang, Z.-Y., Robinson, G.E., Tobe, S.S., Yagi, K.J., Strambi C, Strambi, A., Stay, B. (1991): Hormonal regulation of behavioural development in the honey bee is based on changes in the rate of juvenile hormone biosynthesis. Journal of Insect Physiology, (37): 733-741.

21. Jay, C.S. (1963): The development of honeybees in their cells. Journal of Apicultural Research, (2): 117-134.

22. Karlson, P., Luscher, M. (1959): 'Pheromones': a new term for a class of biologically active substances. Nature ,(183): 55-56.

23. Katzav-Gozansky, T., Soroker, V., Hefetz, A., Cojocaru, M., Erdmann, D.H., Francke, W. (1997): Plasticity of caste-specific Dufour's gland secretion in the honey bee (Apis mellifera L.). Naturwissenschaften, (84): 238-241.

24. Katzav-Gozansky, T., Soroker, V., Ibarra, F., Francke, W., Hefetz, A. (2001): Dufour's gland secretion of the queen honeybee (Apis mellifera): an egg discriminator pheromone or a queen signal? Behavioral Ecology and Sociobiology, (51): 76-86.

25. Katzav-Gozansky. T., Soroker. V., Francke. W., Hefetz. A. (2003): Honeybee egg-laying workers mimic a queen signal. Insectes Sociaux, (50): 20-23.

26. Keeling, C.I., Slessor, K.N., Higo, H.A., Winston, M.L. (2003): New components of the honey bee (Apis mellifera L.) queen retinue pheromone. Proceedings of the National Academy of Sciences, (100): 4486-4491.

27. Le Conte, Y., Mohammedi, A., Robinson, G.E. (2001): Primer effects of a brood pheromone on honeybee behavioural development. Proceedings of the Royal Society B: Biological Sciences, (268): 163-168.

28. Lensky, Y., Cassier, P., Finkel, A., Teeshbee, A., Schlesinger, R., Delorme-Joulie, C., Levinsohn, M. (1984): Les glandes tarsales de l'abeille mellifique (Apis mellifera L.) reines, ouvrieres et fauxbourdons (Hymenoptera, Apidae). Annales des sciences naturelles, (6): 167-175. 
29. Maisonnasse, A., Lenoir, J.C., Costagliola, G., Beslay, D., Choteau, F., Crauser, D., Becard, J.M., Plettner, E., Le Conte, Y. (2009): A scientific note on E-ß-ocimene, a new volatile primer pheromone that inhibits worker ovary development in honey bees. Apidologie, (40): 562-564.

30. Martin, S.J., Dils, V., Billen J. (2005): Morphology of the Dufour gland within the honey bee sting gland complex. Apidologie, (36): 543-546.

31. Morse, R. A. (1972): Honeybee alarm pheromone: another function. Annals of the Entomological Society of America, (65): 1430.

32. Naumann, K., Winston, M.L., Slessor, K. N. (1993): Movement of honey bee (Apis mellifera L.) queen mandibuar gland pheromone in populous and unpopulous colonies. Journal of Insect Behavior, (6): 211-223.

33. Pankiw, T., Huang, Z.-Y., Winston, M.L., Robinson, G.E. (1998): Queen mandibular gland pheromone influences worker honey bee (Apis mellifera L.) foraging ontogeny and juvenile hormone titers. Journal of Insect Physiology, (44): 685-692.

34. Pankiw, T., Page, R.E. Jr. (2001): Brood pheromone modulates honeybee (Apis mellifera L.) sucrose response thresholds. Behavioral Ecology and Sociobiology, (49): 206-213.

35. Pankiw, T. (2004): Cued in: honey bee pheromones as information flow and collective decisionmaking. Apidologie, (35): 217-226.

36. Pickett, J.A., Williams, I.H., Martin, A.P. (1982): (Z)-11-eicosen-1-ol, an important new pheromonal component from the sting of the honey bee, Apis mellifera L. Journal of Chemical Ecology, (8): 163-175.

37. Ratnieks, F.L.W. (1993): Egg-laying, egg-removal, and ovary development by workers in queenright honey-bee colonies. Behavioral Ecology and Sociobiology, (32): 191-198.

38. Rinderer, T.E., Baxter, J.R. (1979.): Honey bee hoarding behaviour: Effect of previous stimulation by empty comb. Animal Behaviour, (27): 426-428.

39. Rinderer, T.E., Hagstad, W.A. (1984): The effect of empty comb on the proportion of foraging honeybees collecting nectar. Journal of Apicultural Research, 23(2): 80-81.

40. Robinson, G.E. (1992): Regulation of division of labor in insect societies. Annual Review of Entomology, (37): 637-665.

41. Ruttner, F. (1966): The life and flight activity of drones. Bee World, (47): 93-101.

42. Shearer, D.A., Boch, R. (1965): 2-heptanone in the mandibular gland secretion of the honey bee. Nature, (206): 530.

43. Slessor, K.N., Kaminski, L.-A., King, G.G.S., Borden, J.H., Winston, M.L. (1988): Semiochemical basis of the retinue response to queen honey bees. Nature, (332): 354-356.

44. Slessor, K.N., Winston, M.L., Le Conte, Y. (2005): Pheromone communication in the honeybee (Apis mellifera L.). Journal of Chemical Ecology, 31(11): 2731-2745.

45. Smith, R.K., Spivak, M., Taylor, O.R., Bennett, C., Smith, M.L. (1993): Maturation of tergal gland alkene profiles in European honey bee queens, Apis mellifera L. Journal of Chemical Ecology, (19): 133-142.

46. Snodgras, R.E. (1956): Tha Anatomy of the Honey Bee. Cornell Univ. Press, Ithaca, New York

47. Stout, J.C., Goulson, D. (2001): The use of conspecific andinterspecific scent marks by foraging bumblebees and honeybees. Animal Behaviour, (62): 183-189. 
48. Traynor, K.S., Le Conste, Y., Page, R.E.Jr. (2014): Queen and young larval pheromones impact nursing and reproductive physiology of honey bee (Apis mellifera) workers. Behavioral Ecology and Sociobiology, (68): 2059-2073.

49. Velthuis, H.H.W. (1970): Ovarian development in Apis mellifera worker bees. Entomologia Experimentalis et Applicata, (13): 377-394.

50. Wager, B. R., Breed, M. (2000): Does honey bee sting alarm pheromone give orientation information to defensive bees? Annals of the Entomological Society of America, (93): 329-332.

51. Whitcomb, W. (1946): Feeding bees for comb production. Gleanings in Bee Culture, 74(4): 198202.

52. Wilson, E.O. i Bosser, W.H. (1963): Chemical communication among animals. Recent progress in hormone research, (19): 673-716.

53. Winston, M.L. (1987): The Biology of the Honey Bee. Harvard University Press, Cambridge, Massachusetts, London

54. Winston, M.L., Higo, H.A., Slessor K.N. (1990): Effect of various dosages of queen mandibular gland pheromone on the inhibition of queen rearing in the honey bee (Hymenoptera: Apidae). Entomological Society of America, (83): 234-238.

55. Wossler, T.C., Crewe, R.M. (1999): Mass spectral identification of the tergal gland secretions of female castes of two African honey bee races (Apis mellifera). Journal of Apicultural Research, (38): 137-148.

56. Zmarlicki, C., Morse, R.A. (1963): Drone congregation areas. Journal of Apicultural Research, (2): 64-66.

\section{PHEROMONES OF THE HONEY BEE (Apis mellifera L.)}

\section{Summary}

Division of labor among members and functioning of the honey bee colonies provides perfect communication, which in honey bee colony takes place by means of waggle dance and mainly with pheromones. Pheromones in the honey bee colony have a role in connecting honey bees as individuals in a cohesive community, so-called superorganism. Also, pheromones play a key role in all aspects of life in honey bee colonies, from reproduction to collecting food and colony defense. In this review are described the glands that secrete pheromones and the role of individual pheromones on the behavior of honey bee colony.

Key words: Honey bee, pheromones, glands, comunication

Primljeno - Received: 16.06.2017.

Prihvaćeno - Accepted: 09.07.2017. 